\title{
The Last Mufti of Iranian Kurdistan and Its Revision of Kurdish History
}

\author{
Marouf Cabi ${ }^{1}$ \\ University of St Andrews, Scotland
}

\begin{abstract}
This article analysis Ali Ezzatyar's The Last Mufti of Iranian Kurdistan, which aims to prove how the Kurds' supposed indisposition towards political Islam qualifies them to be the natural allies of the West and the Western powers. Supported by the two theses of shared social values and shared rivalries between the Kurds and the West, and centred around its main protagonist Ahmad Muftizadeh's supposedly alternative form of political Islam, the book is based on two premises: a declining relationship throughout the twentieth century between Kurdish identity and Islamism, and the inconsequential nature of the relationship between Iranian Islamism and Kurdish Islamism. In contrast, and in order to save history from merely serving policy-making, this article argues that the relationships involved were determined in the wider context of the process of the modernization of Iran, in which political Islam emerged and, albeit to a limited extent, influenced the development of a religious Kurdayeti or Kurdishness represented by Muftizadeh.
\end{abstract}

Keywords: Kurdish religious identity, political Islam, modernization, Ahmad Muftizadeh, religious Kurdayeti.

\section{Introduction}

The Last Mufti of Iranian Kurdistan: Ethnic and Religious Implications in the Greater Middle East, written by Ali Ezzatyar, an American diplomat, was published in 2016. The book covers the life of Ahmad Muftizadeh (1933-1993) a Kurdish political activist who matured into a religious thinker and a critic of the Pahlavi monarchy (1925-1979) during the two decades prior to the popular or Islamic Revolution of 1979 in Iran. Upon the triumph of the Revolution, Muftizadeh began to advocate an "Islamic autonomy" for the Kurds. Although not clearly articulated, Islamic autonomy distinguished his ideas for Kurdish self-rule from the approaches of other Kurdish and Iranian political forces at a time when the idea of an Islamic Republic had become widespread across Iran. Islamic autonomy was based on the idea of an Islamic government which derived its legitimacy, according to Muftizadeh, from Shuray-e Eslami or an Islamic council, in which, unlike in Western parliaments, the sovereignty of the people was completely guaranteed (see Muftizadeh, 1979). However, he failed to mobilize the people, who were increasingly attracted to new, non-religious Kurdish political parties. Simultaneously, the bellicose stance of the new regime towards the Kurds and its brutal reaction to the Kurdish autonomy movement between 1979 and 1980, accelerated the demise of Muftizadeh, whose unsuccessful attempts at reconciliation and mutual understanding came to be wrongly seen by the Kurds as siding with the government, though other miscalculations and his contributions to social tensions also worked against him. I argue that he was a victim of post-revolutionary hardening stances towards politics, and of the new regime's ethnic intolerance.

Ahmad Muftizadeh's tale, therefore, deserves to be told, to increase our historical awareness; Part II of Ezzatyar's book uncovers previously untold but important details of the life of this exceptional, scrupulous man, who ultimately experienced prolonged incarceration before his death. He died under house arrest in 1993, shortly after he had been released from a long spell in prison. That said, the book also pursues other political goals. By conflating the histories of various Kurdish societies (Faltis, 2014), it presents a rather vaguely reconstructed Kurdish history to support a policy argument in the present, identifying the Kurds as "the best allies of the West". A vagueness also results from a homogenous treatment of the Kurds in the region. Illustrating this, while the book argues that the Kurds under the Kurdish Regional Government (KRG) in Iraq, presumably as a fledging state, deserves the support of the West, it does not support its assertion that the Kurds in Iran require the same assistance.

The book reconstructs Kurdish history around two main premises, supported by two other theses. In this reconstructed history, the relationship between Islamism in Kurdistan and Kurdish national identity shows a decline from the end of the nineteenth century to the present. This trend also applies to the relationship between Islamism in Kurdistan and Islamism in Iran. The ascendency of Kurdish national identity over Islamism is represented in the decline of the religious leadership of Kurdish movements, while, the book argues, a weak relationship between the two kinds of Islamism throughout the histories of (Iranian) Kurdistan and Iran is selfevident because of the way the latter unfolded in the twentieth century, eventually bringing about the Islamic Revolution and the establishment of an Islamic state. The existence of Ahmad Muftizadeh's political Islam does

\footnotetext{
${ }^{1}$ Correspondence: Tutor in history, email: maroufcabi@gmail.com
} 
not disqualify these claims; on the contrary, he confirms the book's assumed Kurdish indisposition towards politicized religion.

The first part of this review places the concepts involved, while undefined in the book, in their historical contexts, and argues that although the claim of the Kurds' indisposition is ahistorical, we still need to satisfactorily explain the aversion to religious extremism among the Kurds, to avoid slipping into the belief in a people's inherent qualities. It is true that the political forces in Kurdish movements have been mainly characterized by secular programmes, and politically active Kurdish religious figures and organizations can rarely be categorised as extremist. However, dispositions are shaped in historical contexts, and not in a linear history progressing down one path, which unfortunately characterizes the book's premises. Just as crucially, to avoid such a homogenous approach to concepts of Kurds and Kurdistan, we need to stress that different Kurdish societies have experienced different contexts, acquiring a kind of political field peculiar to each despite undeniable commonalities. From this perspective, the prevailing "Islamism" in Iran is only comprehensible in relation to the authoritarian, 'westernizing' modernization of Iran which intensified in the decades preceding the 1979 Revolution. $^{2}$ It was in the same context that Muftizadeh's political Islam was shaped. This is elaborated below, but for another illustration of the link between attitudes towards political religion and the political context, the current popularity and ascendency of religious nationalism in the KRG, the social, economic, cultural and political plans of which have clearly failed, is instructive. Therefore, assuming a steady decline of "Islamism" in different parts of Kurdistan or anywhere else, is not based on an historical analysis of a phenomenon, which in fact mutates according to different historical contexts and conjunctures.

Furthermore, the theses of "shared social values" and "shared rivalries" between the book's imagined "Kurds" and the "West", support its main argument to elevate the Kurds to the rank of the United States' natural allies. However, the former is based on a flawed assumption of a secularism, assumed as represented by the Kurds' and the West's seemingly shared indisposition towards extremism and shared progressive views, exemplified, the book argues, by views towards women. The view that the Kurds are historically and intrinsically secular has, indeed, become highly popular among Kurds themselves. The latter argument is based on international alliances of antagonistic sides. Therefore, current international rivalries, the book argues, dictate the alliance of the Kurds and the West (namely the United States) because of supposed shared enemies. In the scope of this review, I avoid discussing this topic in relation to the Kurds of other countries, such as Turkey.

The next part of this review discusses the nature of the Iranian Revolution in relation to Muftizadeh's political Islam, because the desire of the (Shi'a) religious authorities in Iran to obtain political power was a modern departure from accepted Islamic tradition. This departure took place as the result of Iran's rapid modernization. This does not imply that an Islamic government in Iran was inevitable, since ultimately it was the actions of the participants, among them the liberal and radicals, which determined the fate of the Revolution. Ultimately, the radicals triumphed because their political ideas had gained hegemony, in Gramscian sense, in the two decades that preceded the Revolution. This takes us to the next section which is an assessment of Iranian Kurdistan during the Revolution. This is necessary because the book's narrative is inadequate, and aims to serve the author's premises and theses. To prevent the reoccurrence of Muftizadeh's historical victimhood, this is followed by a discussion of the phenomenon of Ahmad Muftizadeh, in order to assign him a more appropriate place in Kurdish history.

\title{
Kurdish History or a Policy Argument?
}

The book is an extended policy argument to persuade policy-makers in the West, particularly the United States, to accept the idea that the Kurds are the West's "natural allies" in the role it will play in the region in the future:

\begin{abstract}
What will be the legacy of the Islamic State in the minds of marginalized Muslims for the next 100 years in places like Pakistan and Malaysia, even if the Islamic State is destroyed? Where can America salvage some influence and, at the very least, ensure the safety of its citizens? These will be the defining foreign policy questions of the next decades. In this text, we examine why Kurdistan is essential to addressing all of them. (Ezzatyar, 2016, p. 6)
\end{abstract}

The answer of the book to these questions develops around a historical narrative of a presumed aversion of the Kurds to Islamic extremism, the "other" of what the "West" is claimed to stand for. At the same time, the nomination of the Kurds as natural allies of the West derives from the book's theses of "shared social values" and "shared rivalries" in international relations. The Kurds' "increasingly shared social values with the West" means they "remain a stalwart long-term partner [for the West] in the Middle East" while shared rivalries, based on historical evidence, "tend to make consistent allies", e.g. in the same way that the "Syria's alliance with Iran during

\footnotetext{
2 "Westernization" here refers to the state's imposition and inculcation of its preferred aspects of what was deemed a Western way of life because of its origins. In such circumstances, a democratic and progressive perception of modernity inspired a generation to engage actively in social change, by adopting cultural innovations originating in Western countries.
} 
the Iran-Iraq war" was formed (Ezzatyar, 2016, p. 211). The book's historical conceptualisation of Islamism is based on the premise of a declining relationship between Islamism and Kurdish identity, with the effect that over the twentieth century, the connection between the two became inconsequential (Ezzatyar, 2016, p. 38). Simultaneously, Ezzatyar maintains, the relationship between Islamism in (Iranian?) Kurdistan and Islamism in Iran, has become insignificant. The evidence for these claims comes from a declining role of religious figures, such as Sheikhs, in the leadership of Kurdish movements, and Iran's Islamic Republic (Ezzatyar, 2016, p. 38-39). ${ }^{3}$ Therefore, "Kurdistan's indisposition to Islamism is particularly valuable in this era where extremist religious ideology is a primary cause of instability" in the region (Ezzatyar, 2016, p. 212). The narrative is followed by a prediction about the future, backed by the example of Ahmad Muftizadeh:

For the reasons outlined in this book, significant political moments based on Islam are not likely to develop in Kurdistan today or in the near future. Ahmad Moftizadeh's story is part of an ideological evolution in Kurdistan which establishes the limits of political Islam in Kurdish society (Ezzatyar, 2016, p. 212).

If any American policy-maker still has doubts, Muftizadeh's progressive attitude towards women seals the deal. The book quotes him arguing that "Nowhere in the Qur'an does it say that a man is higher than a woman" (Ezzatyar, 2016, p. 177). Indeed, the author concludes, based on Muftizadeh's views on women expressed in many of his letters, that "his views on women's role in the family, religious life, and decision making can be appropriately described as highly progressive, particularly among Islamic interpretations" (Ezzatyar, 2016, p. 117). However, such "progressive" views towards women are not isolated and unique to Muftizadeh's thought, but have roots in the reformist school of Islam, and can be detected in the views and works of scholars such as Muhammad 'Abdu (1849-1905) and his disciple Qasim Amin (1865-1908), an Egyptian lawyer, emerging at the end of the nineteenth century. Mufitzadeh's views in this respect cannot be regarded as an intellectual innovation. Reformist Islam was not only a form of resistance to Europe's cultural onslaught on the Islamic world (Tolba, 2018). The views of 'Abdu, a disciple of Jamal ad-Din Afghani, an Islamic jurist and Mufti of Egypt between 1899 and 1905, were that religion should be based on rationality: "Abdu regarded past traditions as products of history and not rules for the present", and believed that "Islamic thought had to be based on rationality and scientific development" (Pappe, 2005, p. 233). In his Liberation of Women, first published in Arabic in 1899 as Tahrir al-mar'a, Amin argued that the degradation of women was non-Islamic and contrary to the Prophet Muhammad's teaching, intertwining the emancipation of Egypt with the emancipation of women. According to Amin,

The Islamic legal system, the Shari'a, stipulated the equality of women and men before any other legal system. Islam declared women's freedom and emancipation, and granted women all human rights during a time when women occupied the lowest status in all societies (Amin, 2000, p. 7).

His position on the veil was to avoid extremities:

Westerners have gone too far in the exposure of their women so that it is difficult for a Western woman to guard herself from sensuous desires and unacceptable shameful feelings. We, on the other hand, have gone to extreme in veiling our women and prohibiting them from appearing unveiled before men, to such extent that we turn women into objects or goods we own (Amin, 2000, p. 35-36).

Nevertheless, Amin was adamant in exposing the inferior social status of women in Egypt and explained clearly that the veil was not a custom peculiar to Muslims: "It was a prevalent custom in many nations [before Islam] and its disappearance was the result of the societal changes which accompanied the change and progress of civilization" (Amin, 2000, p. 37). His reformist views on marriage and divorce, and his condemnation of polygamy, follow a "progressive" view of women, justified by Islamic reasoning (Amin, 2000, p. 76-100). However, Amin's Islamic reformism called for only partial equality for women, excluding them from politics and positions of leadership. Amin was concerned, as can be seen in the title of his next book, with the notion of "new woman", because the "old woman" was not compatible with the new nation, thus making nationalism and women's emancipation inseparable (for more see Amin, 2000, p. 62-75).

Attempts to redefine the role of women in society were made in the literature, particularly the poetry, of Islamic regions since the early twentieth century. For example, the Iraqi poet Jamil Sidqqi al-Zahawi (1863-1936) wrote: "Tear away the veil, women of Iraq, unveil yourself! For life needs transformation. Tear it away, burn it,

\footnotetext{
${ }^{3}$ These claims are supported by using different Tables.
} 
do not hesitate. It has given you only false protection" (quoted in Pappe, 2005, p. 232-233). Al-Zahawi called "for the removal of the veil in the name of religious purity and in response to Western feminism" (Pappe, 2005, p. 233). Similarly, Kurdish poetry represented by likes of Piramerd, Fayaq Bekas, Qane' and Hemin began to cultivate the idea of a new, educated woman and her role in the making of the new nation by undermining the veil and traditional duties assigned for women. Pappe's interpretation of al-Zahawi's poetry as quoted, as a response to Western feminism, is relevant. It seems that as the century moved forward, the earlier Islamic reformism's fusion of Islamism, nationalism and feminism, was supplanted by Islamism's break with (secular) nationalism and (westernizing) feminism.

Therefore, Muftizadeh's "progressive" views towards women, which took shape at earliest towards the end of the 1960s, may be regarded as "regressive" when they are evaluated in the light of the history of the development of Islam in the late nineteenth and twentieth centuries in a country like Egypt. This is highlighted when it is considered that Muftizadeh's Islamic reformism offers nothing more radical than that of, for example, Amin, while it is more clearly distinguishable from contemporary secular nationalism and feminism in Iran, unlike earlier in the century. Nor is there anything necessarily "Kurdish" about his views on the role of women in society. In the reconstructed history to show a declining relationship between Islamism and Kurdish identity, "woman" becomes a touchstone to measure "progress" and "secularism".

Especially in a time when religious extremism constitutes a prominent characteristic of the region, the popular presumption of the Kurds' historical indisposition towards religious extremism becomes attractive to the West. This has led many to search for factors which can explain this phenomenon. However, reading history backwards, or looking for evidence which supports a historian's premise about the present, has repeatedly been proved an inadequate method. The idea is attractive at first, but in actuality is revealed as very problematic, in the search for historical evidence. First, where aversion to extremism can be shown, it can be attributed to many factors, with the supposed decline of the religious leadership of the Kurdish movements at best only one factor among many. Secondly, history demonstrates that the ascendancy of national identity over religious identity has not always resulted in indisposition towards extremism. For example, Arab identity played a central role in various nation-states in the Arab world, but strong religious movements also arose in these states, first to resist foreign occupations, and then as the expression of discontent with uncritical westernization and authoritarianism. Moreover, such movements were not always extremist. For example, the Muslim Brotherhood emerged in Egypt in the context of anti-colonial struggle, and developed in the context of nation-building and state-led modernization of society and the state. It changed its shape and agenda throughout these processes. Hasan al-Bana and Sayyed Qutib, the respective founder and subsequent leader of the Brotherhood, were not identical in their outlooks. AlBana saw his Islamism as a response to colonialism, voicing the social grievances of Egyptians, whereas the latter oversaw a decisive turn towards the idea of an Islamic government in the Middle East, "rooted in major contemporary processes of social and political change in the second half of the twentieth century" (Arjomand, 2010 , p. 173). Since the 1940s "an intellectual breakthrough from an orthodox reformism to Islamic ideology" had taken place, pioneered by Mawláná Sayyid Abu'l A‘lá Mawdudí (d.1979), the founder of Jama'at-i Islami in Lahore (see Arjomand, 2010, p. 180).

Rapidly changing social conditions and intellectual transformations, simultaneously taking place in Egypt and in Iran, had made the idea of an Islamic government attractive; and for this reason, Ahmad Muftizadeh was attracted to the political ideas advocated by Qutib. This is ignored by the book, which does not seem to appreciate the relation between historical contexts and ideologies. Muftizadeh's attraction to Qutib is noteworthy. As will be seen below, contradicting Ezzatyar's belief in the historical decline of Kurdish Islamism, this development came later in Muftizadeh's life, signifying that there had been support for political Islam. The degree of political activism and "extremism" of any movement or figure, is determined within transforming historical contexts, in which many interrelated factors interact. While modern political Islam and the cry for an Islamic government were theoretically derived from the intellectual transformations of the post-World War II era, all these ideas are only understandable in their historical context of the authoritarian modernization of "secular" nation-states, which uncritically embraced modernization and development theories to build great nations. Should not historians also be puzzled by the question of why Nasser's and Pahlavi's "secularism" in Egypt and Iran result in a radicalized Brotherhood and an Islamic government respectively, not in more democratic secular social systems? Which conditions shape desires for radicalization, national or religious alike? It may be more illuminating to focus on social, culturalgender, political, and economic policies of twentieth-century modern states, Iran being a case in point. As Sami Zubaida, whose writing the author prefers to ignore in favour of the likes of Samuel Huntington, rightly argues, the ideological constructions of the Iranian Revolution, e.g. the guardianship of the jurists, assigned

the function of a political leadership and rule to a just faqih [jurist] (in this case Khomeini) [...] were unprecedented in traditional Shi'ite thought which distinguished, implicitly, between state and religious community [...] dominant Twelver thought from as early as the sixth Imam, Ja'far al-Sadiq, distanced the imamate from politics in favour of a philosophical and mystical conception. There were, of course, many departures from this concept over the centuries, in relation to particular situations. Khomeini's departure [...] making the faqih into a prince 
and denouncing monarchy, was more credible, if not thinkable, in the context of a modern nation-state, in which the Muslim people, as nation and historical subjects, will choose to be ruled by Islam, and by the only true embodiment of Islamic knowledge and justice, the 'Just Faqih' (2009, p. x).

Intriguingly, the political concept of "Republic" was also unprecedented in Islamic thought. Therefore, the relationship between Islamism and Kurdish identity should be evaluated in the context of nation-states. However, and this is a crucial point, there have not been identical socio-economic and cultural transformations in the states in which the Kurds live. Each state should be analyzed separately to avoid a homogenous approach to the concepts of Kurds and Kurdistan.

To present a more comprehensive analysis, we need to evaluate the ostensible inclination of the Kurdish movements to secular and progressive ideas in light of historical factors of which, two are prominent. First, as Nikki Keddie (1997) rightly argues, a religious minority inclines towards secularism to gain more religious rights in a biased religious state (34). This situation can have more democratic implications for religious, social or political activism among minorities. This, combined with the distinct cultural characteristics, were influential factors which made the search for authenticity and nativism by some intellectuals during the period of Pahlavi modernization (see Mirsepassi, 2011, p. 85-128), largely irrelevant in Iranian Kurdistan. Secondly, the history of Iran in the twentieth century included formidable campaigns to eradicate religious, gender and ethnic prejudices, a growing educated generation, left-wing parties, intellectuals, writers, women activists, and so on. Indeed, the Kurdish movement since World War II continued to undergo intellectual/ideological transformations in close relation with other movements across Iran, influenced by contemporary regional and international revolutions and movements. In this context, especially in the 1960s and 1970s, there emerged a generation of Kurdish urban activists, including Ahmad Muftizadeh, who were the product of modern education as well as the social and political developments Iran was experiencing at the time. It was in the same period that the nuclei of modern Kurdish political parties in Iran were formed.

Another crucial, though neglected, aspect of modern Kurdish histories, are the non-identical formations of modern Kurdish societies in different nation-states in the last century. While historical and cultural commonalities among the Kurds in modern times continued, Kurdish societies began to strengthen or acquire common social or cultural bonds with non-Kurdish societies in the dual process of socio-economic and political modernization which resulted in the Kurds' socio-economic integration on the one hand, and cultural/ethnic resistance (modern Kurdayeti) on the other. Put differently, Kurdish-Iranian society is a synthesis of both its cultural resistance against the modernization's nationalization and homogenization of identity, and its socioeconomic interaction with other societies in Iran. Crucially, one important consequence of the dual process has been "shared social values" between diverse societies in the modern nation-states. There are other Iranian societies which exhibit indisposition to religious extremism, and share social values with the Kurds. Therefore, international support for any nascent state, such as the KRG, which must be committed to democracy, is always welcome. However, such support should not be seen as a tool to further Western interests and destabilize the region.

As mentioned above, there has been a strong tendency to assess an "underdeveloped" society's progress with the criterion of women's status and rights. The post-World War II development discourse has objectified and visualized "woman" as a category (Escobar, 1995, p. 171). Accordingly, based on development and modernization theories, westernizing modernization has created a popular perception which intimately linked "women" with "secularism" and "modernization" (for modernization theories see Inkeles \& Smith, 1974; Lerner, 1958). In this perception, secularism is wrongly regarded as a necessary component of modernization, which is perceived as a necessary "transition" to "becoming modern". ${ }^{4}$ This modernizing aspect of secularism has mainly served authoritarian states, which excluded popular political participation, to create a secular society based on the separation of religion and state. In regard to women, the centralizing state-led developments in the nation-states generally tended to create a "westernized", "progressive" image of woman. This was the case in Iran, though the enhancement of women's social status in that country owed itself to the state's modern education, laws and centres which were inspired by a widespread women movement called nehzat-e zanan. Many women's societies and organizations were already representing the movement by the early 1960s (cf. Afkhami, 2003). By the end of the 1970s, Iran, including its Kurdish society, with its gender order shaken, was characterized by a new generation of women. This was owed not only to the peculiarities of Kurdish identity or Kurdish culture, but crucially to an almost century-old socio-economic and historical transformation of Iran, in which women's activism across that country played a prominent role. Indeed, a comparative study of the social status of Kurdish women, for example in Iran and Iraq, will reveal differences which can best be explained by differing levels of women's civil society

\footnotetext{
${ }^{4}$ For critiques of modernization, traditional and modern cf. Reinhard, 1967; Pappe, 2005, p. 1-13; Lockman, 2010 , p. 134-48.
} 
activism. ${ }^{5}$ Therefore, the relationship between religious identity and national identity, and with the question of woman, are perceivable in the light of many interrelated historical factors.

\section{Ahmad Muftizadeh in Historical Narrative}

In The Last Mufti of Iranian Kurdistan, Ahmad Muftizadeh has a central role in Ezzatyar's attempt to prove the presumption of the Kurds' aversion to extremism, and to impart a prophecy about the future (already invalidated in the wake of the Kurdish Referendum of September 2017, which resulted in a political failure and reversal of fortune for the KRG). Unwittingly perhaps, Muftizadeh's victimhood is recreated in Ezzatyar's book, as he is denied his rightful place in the history of a certain period of Iranian Kurdistan. In contrast, I argue that Ahmad Muftizadeh signified a religious Kurdayeti (Kurdishness), which simultaneously responded to cultural homogenization and, to a lesser degree than Islamist thinking in the rest of Iran, the westernization of culture. ${ }^{6}$ The notion of religious Kurdayeti asserts that religion has been a formative aspect in inspiring individual endeavours or organized movements for the political, cultural and social rights of the Kurds; it is distinguished from other movements or political parties whose ideologies are defined in non-religious terms. Therefore, focus should be placed on some of the cultural consequences of the Pahlavis' modernization which intensified during the 1960s and 1970s, and on the nature of the 1979 Revolution.

The debate over whether the Revolution was Islamic or not has been heated. At least there seems to be a consensus that the Revolution's Islamic facet gradually overtook the Revolution's other secular and liberal facets. This question is relevant in determining the role of Ahmad Muftizadeh in the political and religious activism of the era. The triumph of the Islamic Revolution was neither a historical accident, nor the result of the policies of the superpowers, which according to a popular discourse made an "unknown", Ayatollah Khomeini, famous overnight. Neither was it an inevitable outcome of modernization. Contingencies and external factors undoubtedly play their role in history. However, in this case, one should recognize, to borrow from Gramsci, "the preceding cultural period" which (in the case of Iran) resulted in the cultural and political hegemony of the religious opposition (Forgacs, 2000, p. 58). Unacceptably for the inflexible leftist, liberal and royalist historiographies, the Islamization of the Revolution was rooted in a cultural hegemony that the religious opposition to the monarchy had achieved through the era of the Shah's "White Revolution" (1963-1979). The White Revolution aimed to make Iran a "Great Civilisation" through profound socio-economic and cultural transformations. Not only did it reflect the long-held genuine desire of Iranians for reform since the Constitutional Revolution (1906-11), it also aimed to prevent social revolution from below (see Louis, 1984, p. 632-689). Equally crucial, following the coup against the democratically elected Prime Minister Mohammad Mosaddegh in 1953, Iranian politics came to be characterized by an oppressive regime. However, with the Pahlavi regime emboldened by soaring oil revenues, its socio-economic plans revolutionized Iran, shaking the countries' socio-economic foundations and transforming its cultural image. The modernization was characterized by unbridled economic expansion and urbanization, rapid "westernization" of culture through new visual media especially the cinema and film industry (Yigit \& Tatch, 2017), and, finally, by the concentration of political power and increased political oppression. Consequently, the state-led modernization entailed massive waves of migration from the countryside to cities, the expansion of the low-income working class, the enrichment of the upper middle class which widened the existing income gaps, political corruption, and financial embezzlement. At the same time, the regime became heavily reliant on the notorious, omnipresent intelligent service SAVAK, expensive armament programmes and extravagant spending, the latter exemplified by the 2,500 ${ }^{\text {th }}$ Celebration of the Iranian Monarchy in 1971.

Modernization transformed Iran in many ways but, most relevant to our discussion, it also transformed the nature of the Shi'a religious establishment's involvement in politics. Especially since the early 1940s, the Islamic movement in Iran had become increasingly revolutionary and politicized, manifested in the leadership of the militant activists. They deployed "clandestine political journalism and organization while using religious sermons as a political platform [and creating] cooperation between the militant clerics and petty bourgeois intellectuals" (Arjomand, 1988, p. 96-97). Moreover, Islamic associations grew, and the number of trained mujtahids (Arabic/Persian, interpreters of the texts on Shari'a law) increased, adding to the already considerable number of religious functionaries, major and minor mosques, seminaries and religious schools, all of which were financially sanctioned by vaqfs, the offices of religious endowments, as well as religious taxes (see Arjomand, 1988, p. 96; Yapp, 1996, p. 337). After the death of Hossain Borujerdi, the marja'e taqlid (Persian, source of emulation, the highest position in the Shi'a religious hierarchy), in 1961, Khomeini became an outspoken critic of the Pahlavis' modernization; consequently, he was sent into exile after the bloody uprising of 1963. The Iranian religious establishment ceased to function merely as an institution for providing advice to the monarch, mutating

\footnotetext{
${ }^{5}$ This is an understudied subject. However, ostensibly more organized involvement of Kurdish-Iranian women in politics reflects different degree of socio-economic, cultural and political transformations in the two countries.

${ }^{6}$ Although Kurdayeti denotes both a worldview and a cultural movement that are based on a national understanding of self and history, it does not simply mean "Kurdish nationalism". It refers to both a sense of belonging to the Kurdish people, and the struggle for their justified cultural and ethnic rights. As an ideology, nationalism can be rejected by many who are receptive of Kurdayeti also as a way of life.
} 
into a movement against the monarchy itself, advocating an Islamic government. The religious opposition, although benefiting from the state's leniency in suppressing them in comparison to the way it suppressed the left, embarked on a campaign to engage the population in politics through religious sermons in places of worship such as mosques and Hossainyas, and by employing the relatively new means of communication, such as cassette tapes, by which religious activists spread political messages, including recordings of the speeches of Ayatollah Khomeini (Yapp, 1996, p. 334). In this way, the religious opposition's idea of Islamic government became an attractive political alternative for a large part of the Iranian population. Before the religious establishment succeeded in usurping political power, it had succeeded in winning the hearts and minds of a large section of the society, exerting considerable social hegemony. Therefore, the common claim, that on the eve of the 1979 Revolution, the European powers' radio broadcasts made Ayatollah Khomeini famous almost overnight and the natural replacement for the outgoing Shah, is based on a flawed interpretation. It loses its credibility in the face of a more extensive analysis of the modernization of Iran and its consequences. Methodologies determine what one desires to see in the past. For example, an approach which identifies the Shah's White Revolution as a "secular" project and ignores the reasons for the advance of the religious opposition during the same period, rests on different understanding of secularism and modernization than the one which adopts a more critical reading of modernization as a transition to "becoming modern" and secularization as a necessary component (see Keddie, 1997).

There may have been other factors which smoothed the path of the Shi'a religious opposition to power, and here historical contingency against "the laws of history" stands out. Just as important was the agency of leading individuals. For example, the religious radicals of the Revolution, who unequivocally supported the idea of an Islamic government, side-lined religious liberals such as the Mehdi Bazargan, the first prime minister after the Revolution, and his Nehzat-e Azadi (Persian, the Freedom Movement). This eventually materialized in the occupation of the American Embassy in Tehran at the end of 1979, followed by Bazargan's resignation. The Islamic Republic had been accepted by most Iranians, but this did not obviate the need for the regime to consolidate itself, hence the use of coercion when necessary. Bazargan's resignation and the occupation of the Embassy were followed by the cultural revolution against the Iranian universities, spearheaded by the incumbent President, Abulhasan Banisadir, and his military decrees against the Kurds. ${ }^{7}$ The outbreak of the Iraq-Iraq War, caused by the Islamic Republic's desire to export revolution to the Arab world, and Iraq's opportunistic invasion of Iran in the summer of 1980 to settle a historical territorial dispute, provided further legitimacy for the regime's retaliation against its opponents (see Amanat, 2017, p. 820-867).

Iran's 1979 Revolution was both popular and Islamic. As a popular revolution, it had many facets which represented different layers of Iranian societies and various intellectual forces. It was an Islamic revolution because the idea of an Islamic government as an alternative to the Pahlavi monarchy had gained cultural hegemony in Iran, and materialized by the end of the Revolution. Identifying the event as the Islamic Revolution, does not ignore the popular nature of the Revolution, nor does it undermine the roles of non-religious forces. It recognizes a process in which an idea becomes hegemonic; and it is in this process which Ahmad Muftizadeh emerged as a religious thinker.

\section{The Muftizadeh Phenomenon}

Ahmad Muftizadeh was the product of an interesting era in the history of modern Iran. He left his imprint on that history in "circumstances given and transmitted by the past." As we read in Ezzatyar's book, he was born into a prominent family. His grandfather had been designated by Naser al-din Shah Qajar (1842-1897) as the Mufti of Qajar Kurdistan, a title which authorized him as the most learned Sunni religious figure to interpret the Islamic shari'a law. Based on "anecdotal evidence", the book claims that the Shah's ministers had struggled to find a learned Sunni clergyman to be consulted by the Shah on a serious religious matter, because there were few known Sunni scholars (Ezzatyar, 2016, p. 55). When the Shah insisted, the reputation of Abdullah Dishi, Ahmad Muftizadeh's grandfather, led the Shah's men to the right person. It is, however, unlikely that at the time there were very few other learned Sunni scholars to be consulted on religious issues, because the Kurdish region under both the Qajar and Ottoman Empires, and ruled by various Kurdish Emirates or Principalities, contained religious schools and produced religious literates since early modern times. Ayatollah Mohammad Mardukh Kurdistani was a descendant of a family of scholars, and himself an authority in the twentieth century.

In any case, after his meeting with the Shah and other religious scholars, the vast religious knowledge of Dishi was so impressive that "he was named the "Mofti" [Mufti] of Iran's Sunnis by Nasser al-Deen Shah. From that point on (around the year 1895), Abdullah Dishi became known as Molla [Mulla] Abdullah Mofti. He became the first official mufti of Iran's Sunnis" (Ezzatyar, 2016, p. 56). However, the accuracy of this story can be disputed, because the book provides no evidence. The book alludes to a scroll "denoting and commemorating Mufti distinction" which is dated 1907 and signed by Ahmad Shah Qajar (r. 1909-25). Nevertheless, the Mufti in

\footnotetext{
${ }^{7}$ Banisadir's military decrees against the Kurds and his announcement of the Cultural Revolution were published by the daily newspaper of Keyhan on 3 April 1979, page 7, and on 22 April 1980, second print, page 1, respectively.
} 
Sanandaj became gradually institutionalized and respected by people. Dishi's son, Ahmad Muftizadeh's father, presided over the institution after his father, and demonstrated his own deep religious knowledge (Biglari, 2017). ${ }^{8}$ As Ezzatyar writes, "Molana Mahmoud [Ahmad's father], who became the longest serving Mofti in the history of Sunni Islam in Iran and Kurdistan generally, came to lead Dar al-Ihsan [Mosque] during the Pahlavi dynasty's ambitious modernization efforts" (Ezzatyar, 2016, p. 59).

The political stances of Molana and his son differed because of two different historical contexts. The latter's time coincided with profound cultural and intellectual transformations. According to Ezzatyar,

\begin{abstract}
Molana Mahmoud was said to have sought a neutral, and as far as religious matters were concerned, cordial relationship with the central government. He did not see himself as an active participant in political matters and there are no salient examples that would demonstrate his being a politicized member of the ulama [...] But there are a number of examples from his life that demonstrate that he harbored some political acumen and nationalist sentiment. This was a result of both his Kurdish cultural awareness, and his view that a mufti's authority is primarily religious and not fully derived from the sovereign (p. 59).
\end{abstract}

The growth of religious opposition during the modernization of Iran does not apply fully to Kurdistan. Most Kurds adhered to a different branch of Islam, Sunni rather than Shi'a, and engaged in the cultural resistance framed by Kurdayeti against ethnic and cultural oppression of the modern state. The dissimilarities between the movements in Kurdistan and the rest of Iran result from a number of religious and cultural factors. The westernizing modernization of Iran threatened Persian cultural dominance, which was bound to a Shi'a Islam which had been represented by an authoritative, hierarchical religious establishment for centuries. At least part a highly influential part - of this establishment, was politically inspired by the modernization of Iran, leading to a fundamental intellectual break with the past by committing itself to political action to seize power. At the same time, the scale of cultural transformation in central Iran and its major urban centres was more profound than elsewhere, for example in the Kurdish region. Therefore, the major cultural and religious components of Kurdayeti functioned as effective barriers to the spread of the Iranian religious movement's influence. This was reinforced by the ideological and intellectual transformations of the time. The new educated generation of the 1960s and 1970s in Iranian Kurdistan inclined towards a socialist or progressive world view, which was preoccupied with social inequalities. With the intensification of cultural and socio-economic modernization, cultural critiques against westernization and social critiques against modernization gained traction, reflecting the intellectual transformations of the time (cf. Barahani, 1363 [1984]; Behrangi, 1382 [2005]). ${ }^{9}$ The Kurdish activism mainly inclined towards social critique, which influenced the ideologies of modern Kurdish parties such as the Democratic Party of Iranian Kurdistan and the Revolutionary Organisation of the Toilers of Iranian Kurdistan-Komala, which emerged during the Revolution, and eventually outmanoeuvred Ahmad Muftizadeh. This was due to their uncompromising stance (particularly Komala's) against the regime, and their eventual response to militarisation with the armed struggle which characterized Iranian Kurdistan throughout the 1980s.

However, this assessment does not imply the complete absence of a religious movement in Kurdistan in the era of the White Revolution. Overlooked by studies of the period in question, modernization stimulated a political and religious trend symbolized by Ahmad Muftizadeh, who eventually came to embody a religious Kurdayeti in 1979. The mufti role offered religious prestige to both the mufti and his descendants, attracting the support of the followers. Ahmad Muftizadeh's grandfather and father resided in Sanandaj, presiding over the religious duties of the population, with their centre in the city's Dar al-Ihsan Mosque. By the time Ahmad was born, the mufti role had been institutionalized to a great extent. In the early 1960s, Ahmad followed his father to Tehran University's School of Theology, where the latter taught; when he fell ill, Ahmad got the opportunity to replace him. Among the other Sunni teachers of the School there was Hajj Abdul Rahman Agha Mohtadi, a member of a notable family of landlords, remnant of the elites of the Kurdistan Republic of 1946 who exerted profound impact on the current generation of Kurdish students and shaped their Kurdish identity (Biglari, 2017; Ezzatyar, 2016: 82). Ahmad Muftizadeh became a regular guest in Mohtadi's residence in Tehran, where meetings on Kurdish culture and literature were held (Biglari, 2017). When he became the son-in-law of Mohtadi the theology teacher in the early 1970s, Ahmad Muftizadeh was already a well-known activist of Kurdish political, cultural and religious rights.

Ahmad Muftizadeh's political activities went back at least to the early 1960s, when he was detained with other Kurdish activists for a period. In these years he distanced himself from the institution of mufti, because it was "deriving its legitimacy from the King" (Ezzatyar, 2016, 69). However, overlooked by Ezzatyar, there seem to have been intellectual reasons too. He had become attracted to Sayyed Qutb's political Islamism and the Muslim

\footnotetext{
${ }^{8}$ As part of the author's doctoral research on the impact of the White Revolution on Kurdish society in Iran, this interview is one in a series of interviews with the permission of the University of St Andrews, Scotland (2017).

${ }^{9}$ Ale Ahmad's Garbzadegi was a more politicized critique of "westernization".
} 
Brotherhood, while he argued for 'scientific' aspects of the Qur'an, and also came to support a Wahhabi interpretation of Sunnism (Biglari, 2017). For such reason, "he ceased to be a Mullah, replaced his clerical dress for men's suits, and a simple life" (Ibid). According to oral accounts, a major ideological as well as organizational break with other activists of (secular) Kurdayeti, had taken place by the middle of the 1970s. Muftizadeh had distanced himself from other Kurdish activists who inclined explicitly to the left, and became more outspoken against the Pahlavi regime. This is exemplified, as Ezzatyar reminds us, by his speech at the funeral of the poet Siwara Ilkanizada, related to the family of Muftizadeh's wife (Ezzatyar, 2016, 108). At the same time, he demonstrated his nascent political Islamism in his critique of followers of the Bahai faith. He took part in a public debate, censuring a prominent Bahai leader in Iran (Biglari, 2017); in the eyes of adherents of other religions in Iran, the Bahais received favour from the Pahlavi regime, to the detriment of others. Moreover, he became more critical of the left and Marxism, decisively distancing him from other Kurdish activists with whom he shared both ideas and organization in the early 1960s. In the 1960s, his commitment to Kurdish activism could not be doubted. In one instance, he intercepted a letter by a Kurdish activist who had written about the political rifts among the Kurdish movement in Iraq, ostensibly "to prevent any possible negative impact on other activists" in Tehran (Ibid). By the middle of the 1970s, however, according to one activist his critique of left-wing ideas "amounted to an antagonistic stance" (Ibid). In effect, prison time in 1964 effectively changed Muftizadeh politically, while the death of his beloved wife of heart failure in 1971 transformed him spiritually, as reflected in his modest, scrupulous lifestyle.

Furthermore, as a religious thinker his social location was also important intellectually and practically. Sanandaj, the provincial centre, more than any other Kurdish city in Iran was affected by westernization through the new means of communication of television and radio, the programmes of which gradually became more westernized (Ayazi, 1371 [1991-2], p. 727). Indeed, a crucial technological development which made Muftizadeh a household name, at least in Sanandaj, was the Kurdish-language television channel based in that city. In the holy month of Ramadan in 1976, when it was decided that a programme on religious matters was to be broadcast in the evenings for the entire month of Ramadan, "there was no question about who would be the most appropriate individual to present on the show" (Ezzatyar, 2016, p. 107). Regarding the existence of an active religious life in Kurdistan, with both intellectual and political components, it is important to remember that Ayatollah Mohammad Mardukh (1880-1975), famous for his History of the Kurds and Kurdistan, was another, more prominent, religious authority who maintained the place of religion in public life in many ways, including his prolific writings. From Sanandaj, too, he contributed to religious debates by engaging in polemics with Shi' a religious thought, writing a pamphlet in the early 1960s in which he claimed null and void the Shi'a concept of sayyed, an honorific term for descendants of the Prophet Mohammad (Biglari, 2017). There were others such as Sheikh Ezzadin Husseini (19222011), Mahabad's Friday Imam in 1979 and the future spokesperson of the Kurdish negotiation mission in 1979 (see below). Husseini's political activities began in the Kurdish Republic and he prioritized Kurdayeti over religion. It may be Husseini, not Muftizadeh, who best supports the argument of The Last Mufti of Kurdistan for the supposed historical aversion of the Kurds to political Islam or Islamist extremism. Although Muftizadeh's political Islam did not explicitly advocate extremism or violence, the Islamization of his politics cannot be doubted. The avoidance of violence is, moreover, best tested in practice. Ahmad Muftizadeh's movement the Maktab-i Qur'an (Kurdish, Qur'anic School) was not an apolitical or very peaceful institution. For example, the tension between Muftizadeh and Safdari, the representative of Khomeini in Kurdistan, contributed to what is known as the Bloody War of Sanandaj in March 1979 just four weeks after the triumph of the Revolution (on the War see Beluri \& Hasan Khali, 2004). ${ }^{10}$ A few month later the Maktab's growing tension with other political and social forces in the city of Mariwan led to a bloody clash on14 July 1979 (see Mostafa Soltani, Mostafa Soltani, Mostafa Soltani 2017, p. 195-97).

The experience of Muftizadeh and Mardukh, and the emergence of Maktab-i Qur'an in 1979, demonstrates that the growth of religious movements, while less prominent than other social movements, was directly linked to the modernization of Iran. In fact, as an idea, Maktab-i Qur'an was the result of Muftizadeh's religious thinking that placed the holy book at the centre of social life. By the middle of the 1970s he had become a critic of "the clergy", superficial ways of interpreting the Qur'an and the Prophet's sayings, and religion which had become, in his view, "empty" for the people (Ezzatyar, 2016, p. 101). Ezzatyar correctly states that "Like Bazargan, the populist Islamism of Ali Shariati [an influential theorist of the Islamic Revolution who died in 1977] also contained elements that were attractive to Moftizadeh" (Ezzatyar, 2016, p. 101). It is important to note that while it is true that religious practices declined as the views of a new educated urban generation increasingly characterized Kurdish society, the Pahlavis' "secularism" did not satisfy everyone, particularly the older generation, which continued to embrace religious practices more actively towards the end of the 1970s. In urban centres, where religious beliefs had shown signs of diminution, exemplified by the adoption of new customs and

10 This booklet includes valuable primary sources which shed light on the causes of the War. It also provides information on other relevant events in March and April 1979 in the Kurdistan Province. 
ways of life, the population gradually became attracted again to religious practices which included hajj pilgrimage and other ceremonies.

The above assessment points to two interpretations. Firstly, the dominant perception of the era of the White Revolution as secularizing, is inadequate to explain the cultural transformations of the era, because it is based on a flawed understanding of secularism. Second, the westernizing modernization of Iran sowed the seeds of modern religious Kurdayeti embodied by the likes of Muftizadeh, whose political stance responded to ethnic and religious prejudices against the Kurds, on the one hand, while his religious thinking critiqued not only the institutional inferiority of the Sunni religion in Iran but also a transforming society, on the other.

\section{The Revolutionary Kurdistan}

Ahmad Muftizadeh's eventual political isolation reflected the political upheavals in Kurdistan following the triumph of the Revolution in February 1979, requiring a detailed analysis. Briefly, the Kurdish movement for autonomy was vehemently denied by the new regime, despite initial promises and later negotiations between Bazargan's provisional government and Kurdish representatives. The situation in Kurdistan during the Revolution and what followed when the new regime consolidated itself, was the historical context in which Muftizadeh's ideas were tested and his fate was determined. His religious nationalism determined his political stance, manifested in the slogan of an Islamic autonomy for the Kurds in Iran. As discussed above, Muftizadeh's outlook had its roots in the Pahlavi modernization in the decades preceding the Revolution. Ezzatyar's essentializing view of Kurdish secularism ignores the fact that the secularism of the deposed monarchy did not prevent the whole spectrum of Kurdish movements involved in the Revolution from being critical of the Pahlavi regime's socio-economic, political, religious and cultural policies, especially during the era of the White Revolution. The 1979 Revolution transformed Kurdish politics for ever, making 'the Kurdish Question' in Iran a permanent feature of Iran's modern politics. That said, the same historical process, with its roots in the period immediately following the Second World War and culminating in the momentous events of 1979, eventually brought about Muftizadeh's isolation as a political force. Although the violent end of a nascent civil society, the regime's ethnic and religious intolerance, and militarization of Iranian Kurdistan, rapidly brought about Muftizadeh's downfall, his religious Kurdayeti has continued to characterize the beliefs of his ardent followers ever since.

\section{Conclusion}

This article attempts to reveal the flaws of a historical narrative, along with its supporting theses the aims of which are to serve a policy argument in the present. The assumptions of a declining relationship between Kurdish religious identity and Kurdish national identity, or between Islamism in Iran and Islamism in Kurdistan, are shown to be untenable in the face of a more comprehensive historical analysis. At the same time, the narrative's creation of a link between "the West" and "the Kurds", based on the theses of "common rivalry" and "common social values", merely benefits Western foreign policies and reveals an essentializing approach. In contrast, this article argues that dispositions or indispositions must be analyzed in connection with the historical contexts within which they are shaped and reshaped. Insofar as the development of political Islam in Iran is concerned, the modernization of Iran in the twentieth century created a new context for an intellectual transformation in favour of an authenticity-seeking nativism. Consequently, this provided political Islam with firm ideological foundations for a rather unconventional but unambiguous appropriation of political power; these foundations were simultaneously cultivated and inspired by prominent figures and movements in the region, which reacted to an undemocratic "modernity" adopted by their "secular" modern states.

Ahmad Muftizadeh's political Islam can be understood in light of this observation. Although the extent of his political Islam or religious critique of the westernizing modernization in the decades preceding the 1979 Revolution was not on the scale of that of the Shi' a religious movement across Iran, he nevertheless symbolized a nascent religious Kurdayeti. His Kurdayeti genuinely pursued cultural, political and religious rights of the Kurds, while his ideas on society and gender were not necessarily "progressive", but nationalist-reformist. In the context of the modernization, specifically in the era of the White Revolution, his political life demonstrates an intellectual journey which became decisively inclined towards political Islam in the mid-1970s (Khosravi, Aghapouri, \& Hamehmorad, 2016). Moreover, it is important to note that his rapid and relatively high popularity in Kurdistan during the Revolution, was not accidental. It attested to the fact that a section of Kurdish society had been already attracted to a religious critique of the monarchy, and also that Muftizadeh himself had already been recognized as a prominent religious critic. In the background, there were profound socio-economic, cultural, political and intellectual transformations. Ironically, his example demonstrates the ascendancy of a politicized religious identity alongside Kurdish national identity, and hence does not corroborate the book's main premises. The fate of this intellectual, with his ideas of Islamic autonomy in Kurdistan, was sealed when he became a victim of the militarization of Kurdistan by an ethnically and religiously intolerant regime. The ascendancy of the new Kurdish political parties, which outmanoeuvred Muftizadeh, ultimately isolated him politically.

By not engaging with such a history, The Last Mufti of Iranian Kurdistan misrepresents Ahmad Muftizadeh and unintentionally perpetuates his historical victimhood. This article's analysis of the emergence of 
a Kurdish political Islam in the context of modernization, serves as a counterargument to the book's premises and theses, which attribute an inherent secular quality to the Kurds. Dispositions and indispositions are not determined by the "progress" of history; they are the products of historical processes and contexts. As such, along with ideologies, they continue to change, and might uncritically be identified as "progressive" or "regressive". A case in point is Kurdish society in Iraq, which is also characterized by a religious Kurdayeti. If the book's premises were credible, we should not have witnessed such a religious movement, represented by many organisations, that continues to present itself as an alternative in the socio-economic, political and cultural process of Kurdish nationbuilding under the KRG. It is true that such movements are not extremist, but this does not necessarily mean intellectual immunity against extremist views. However, where ostensible secularism can be detected among the Kurds, it does not emanate from an inherent quality that others lack or disqualify them as "allies".

Furthermore, while the thesis of common social values treats "the West" and "the Kurds" as monolithic entities, the thesis of common international rivalry reveals the book's raison d'etre, a prediction for the region, which is supposedly going to face more instability, and a request for the U.S. policy-makers to recognise the Kurds as their true allies. The book's prophecy regarding the future effectively undermines its reconstructed Kurdish history, simply because events always seem to take quite a different direction than the one predicted. For this reason, the book's value diminishes in the wake of the Kurdish referendum of September 2017, making its last chapter irrelevant despite the chapter's critical analysis of the KRG. The post-referendum crisis revealed the unpreparedness and political naivety of the KRG, which has now clearly lost its political legitimacy as well a relative cohesiveness that it enjoyed during the preceding decade. By its leaders making the Parliament ineffective, it gradually mutated into an apparatus to create more crises, rather than into a political body able to manage a society. The Kurds in federal Iraq deserve international support to create a responsible democracy, but usurpers of power should not be allowed to propagate a naive culture about the support of a presumed "West", which ironically, despite the effective disintegration of the KRG in the wake of the referendum, never materialized. Similarly, like other peoples in Iran, the Kurds in that country deserve support in their civil struggle for human rights and reform. Indeed, all international communities rely on international support. Therefore, the Kurds in Iran or elsewhere cannot be "allies" to any side in that kind of international relations which is dominated by militaristic attitudes and characterized by hypocrisy.

\section{References}

Afkhami, M. (2003). Zanan, dowlat va jame'e dar Iran: 1941-1978 [Women, State, and Society in Iran 19411978]. Maryland: Foundation for Iranian Studies.

Amanat, A. (2017). Iran: A Modern History. New Haven \& London: Yale University Press.

Amin, Q. (2000). The liberation of women [and] the new woman. Cairo: American University in Cairo Press.

Arjomand, S. A. (1988). The Turban for the crown: The Islamic revolution in Iran. Oxford: Oxford University Press.

Arjomand, S. A. (2010). Islamic Resurgence and Its aftermath. In R. Hefner (Ed.), The New Cambridge History of Islam. Cambridge: Cambridge University Press.

Ayazi, B. (1371 [1991-2]). Ayyine-ye Sanandaj [The Mirror of Sanandaj]. Iran: Payam.

Barahani, R. (1363 [1984]). Tarikhe mozakkar [The masculine history]. Tehran: Nashre Awwal.

Behrangi, A. (Ed.). (1382 [2005]). Majmu'e assare Samad Behrangi [Samad Behrangi's Collected Works). Tabriz: Behrangi.

Beluri, M. and Hasan Khali, M. (2004). Shari Nowroz-i Khwenawi Sina, 1358 [The Bloody War of Sanandaj, 1979.

Biglari, Y. (2017, July 6). Personal Interview.

Escobar, A. (1995). Encountering development: The making and unmaking of the third world. Princeton: Princeton University Press.

Ezzatyar, A. (2016). The last Mufti of Iranian Kurdistan: Ethnic and religious implications in the greater Middle East. New York, NY: Palgrave.

Faltis, C. (2014). Toward a Race Radical Vision of Bilingual Education for Kurdish Users in Turkey: A Commentary. Journal of Ethnic and Cultural Studies, 1(1), 1-5.

Forgacs, D. (Ed.). (2000). The Gramsci Reader: Selected writings 1916-1935. New York: New York University Press.

Inkeles, A., \& Smith, D. H. (1974). Becoming Modern: Individual Change in Six Developing Countries. London: Heinemann.

Keddie, N. R. (1997). Secularism and state: Towards clarity and global comparison. New Left Review 1(226), 2140.

Khosravi, J., Aghapouri, H., \& Hamehmorad, L. (2016). The Islamist Maktab-Quran in Iran and Its Challenges for Kurdish Nationalism. Journal of Ethnic and Cultural Studies, 3(1), 59-73.

Lerner, D. (1958). The passing of the traditional society: Modernizing the Middle East. USA: Free Press. 
Lockman, Z. (2010). The Contending Visions of the Middle East: The History and Politics of Orientalism (2nd ed.). USA: Cambridge University Press.

Louis, W. R. (1984). The British Empire in the Middle East 1945-1951. Oxford: Clarendon Press.

Mirsepassi, A. (2011). Political Islam, Iran, and the Enlightenment. Cambridge: Cambridge University Press.

Mostafa Soltani, M. and R. Mostafa Soltani \& H. Mostafa Soltani (2017). Kak Foad Mostafa Soltani [in Persian] Stettin, Print Group.

Muftizadeh, A. (1979). Hokumat-e Eslami [Islamic Government]. Lectures published by Shuray-e Modiryat-e Maktab-e Qoran [The Managing Council of the Quranic School]. Retrieved from file:///C:/Users/Marouf/Documents/Moftizada/حكومت_اسلامى.pdf, accessed 17/06/2019.

Pappe, I. (2005). The Modern Middle East. New York: Routledge.

Reinhard, B. (1967). Tradition and modernity reconsidered. Comparative Studies in Society and History 9(3), 292346.

Tolba, N. (2018). From Rebellion to Riots. Research In Social Sciences And Technology, 3(2), 93-114. Retrieved from http://ressat.org/index.php/ressat/article/view/358

Yapp, M. E. (1996). The Near East since the first world war: A history to 1995. London: Longman.

Yigit, I. H., \& Tatch, A. (2017). Syrian refugees and Americans: Perceptions, attitudes and insights. American Journal of Qualitative Research, 1(1), 13-31.

Zubaida, S. (2009). Islam, the people and the state: Political ideas and movements in the Middle East. New York: I. B. Tauris. 